\title{
Administration of granulocyte colony-stimulating factor induces immunomodulation, recruitment of $T$ regulatory cells, reduction of myocarditis and decrease of parasite load in a mouse model of chronic Chagas disease cardiomyopathy
}

\author{
Juliana F. Vasconcelos, ${ }^{* \dagger}$ Bruno S. F. Souza, ${ }^{\dagger}, \dagger$ Thayse F. S. Lins, $*$ \\ Letícia M. S. Garcia, ${ }^{\dagger}$ Carla M. Kaneto, ${ }^{\dagger+}{ }^{\ddagger}$ Geraldo P. Sampaio, ${ }^{\dagger}$ \\ Adriano C. de Alcântara, ${ }^{\dagger}$ Cássio S. Meira, ${ }^{*}$ Simone G. Macambira, ${ }^{*},+, \S$ \\ Ricardo Ribeiro-dos-Santos, ${ }^{\dagger}$ and Milena B. P. Soares ${ }^{*,+, 1}$ \\ *Centro de Pesquisas Gonçalo Moniz, Fundação Oswaldo Cruz, Salvador, Bahia, Brazil; ${ }^{\dagger}$ Centro de \\ Biotecnologia e Terapia Celular, Hospital São Rafael, Salvador, Bahia, Brazil; ${ }^{\ddagger}$ Universidade Estadual \\ de Santa Cruz, Ilhéus, Bahia, Brazil; and ${ }^{\S}$ Universidade Federal da Bahia, Salvador, Bahia, Brazil
}

\begin{abstract}
Chagas disease, caused by Trypanosoma cruzi infection, is a leading cause of heart failure in Latin American countries. In a previous study, we showed beneficial effects of granulocyte colony-stimulating factor (G-CSF) administration in the heart function of mice with chronic T. cruzi infection. Presently, we investigated the mechanisms by which this cytokine exerts its beneficial effects. Mice chronically infected with $T$. cruzi were treated with human recombinant G-CSF ( 3 courses of $200 \mu \mathrm{g} / \mathrm{kg} / \mathrm{d}$ for $5 \mathrm{~d}$ ). Inflammation and fibrosis were reduced in the hearts of G-CSFtreated mice, compared with the hearts of vehicle-treated mice, which correlated with decreased syndecan 4 , intercellular adhesion molecule-1, and galectin-3 expressions. Marked reductions in interferon- $\gamma$ and tumor necrosis factor- $\alpha$ and increased interleukin-10 and transforming growth factor- $\beta$ were found after G-CSF administration. Because the therapy did not induce a Th1 to Th2 immune response deviation, we investigated the role of regulatory $T\left(T_{\text {reg }}\right)$ cells. A significant increase in $\mathrm{CD}^{+}{ }^{+} \mathrm{Foxp}^{+}$cells was observed in the hearts of GCSF-treated mice. In addition, a reduction of parasitism was observed after G-CSF treatment. Our results indicate a role of $T_{\text {reg }}$ cells in the immunosuppression induced by G-CSF treatment and reinforces its potential therapeutic use for patients with Chagas disease.Vasconcelos, J. F., Souza, B. S. F., Lins, T. F. S., Garcia,
\end{abstract}

Abbreviations: CCC, chronic chagasic cardiomyopathy; DAPI, 4,6-diamidino-2-phenylindole dihydrochloride; DMEM, Dulbecco's modified Eagle's medium; ELISA, enzyme-linked immunosorbent assay; FBS, fetal bovine serum; Foxp3, forkhead box P3; G-CSF, granulocyte colony-stimulating factor; ICAM-1, intercellular adhesion molecule 1; IL, interleukin; IFN- $\gamma$, interferon- $\gamma$; RT-qPCR, reverse transcription-quantitative polymerase chain reaction; PBS, phosphate-buffered saline; TGF- $\beta$, transforming growth factor- $\beta$; $\mathrm{TNF}-\alpha$, tumor necrosis factor- $\alpha$; $\mathrm{T}_{\text {reg }}$, regulatory $\mathrm{T}$
L. M. S., Kaneto, C. M., Smapaio, G. P., de Alcântara, A. C., Meira, C. S., Macambira, S. G., Ribeiro-dosSantos, R., Soares, M. B. P. Administration of granulocyte colony-stimulating factor induces immunomodulation, recruitment of $T$ regulatory cells, reduction of myocarditis and decrease of parasite load in a mouse model of chronic Chagas disease cardiomyopathy. FASEB J. 27, 4691-4702 (2013). www.fasebj.org

Key Words: Trypanosoma cruzi $\cdot$ cytokine therapy $\cdot$ inflammation - fibrosis Th1 modulation

Chagas disease, CaUSED BY infection with Trypanosoma cruzi, is considered a neglected tropical disease endemic in Latin American countries that mainly affects the poorest populations $(1,2)$. Although recent data indicate a reduction in the number of infected people as a result of vector transmission control, it is estimated that 10 million individuals are infected and 25 million are at risk of acquiring the disease $(3,4)$. About $70 \%$ of infected individuals remain asymptomatic, whereas $30 \%$ will develop the chronic symptomatic form of Chagas disease. Chronic chagasic cardiomyopathy (CCC), the most common symptomatic form of the disease, is one of the leading causes of heart failure. The only available treatment is heart transplantation, a high-cost procedure, that is limited by organ donation and presents severe complications in patients with Chagas disease due to infection reactivation after immunosuppressant administration (5).

\footnotetext{
${ }^{1}$ Correspondence: Centro de Pesquisas Gonçalo Moniz, Fundação Oswaldo Cruz, Rua Waldemar Falcão, 121, Candeal, Salvador, Bahia, Brazil 40296-710. E-mail: milena@ bahia.fiocruz.br

doi: $10.1096 /$ fj.13-229351
} 
Granulocyte colony-stimulating factor (G-CSF) is a pleiotropic cytokine that stimulates the production of neutrophils and releases bone marrow stem cells into the peripheral circulation. It has been in clinical use for nearly 2 decades, mainly as an adjunctive medication to chemotherapy or to mobilize stem cells for bone marrow transplantation (6). In addition to neutrophils and their precursors, monocytes are direct target cells of G-CSF action $(7,8)$. The administration of G-CSF in models of cardiac ischemic diseases has also shown the potential use of this cytokine in regenerative medicine (9-11).

Evidence is now accumulating that G-CSF also has immunomodulatory effects on adaptive immune responses mediated through several mechanisms, including activation of regulatory $\mathrm{T}\left(\mathrm{T}_{\text {reg }}\right)$ cells (12). $\mathrm{T}_{\text {reg }}$ cells express the regulatory lineage factor forkhead box $\mathrm{P} 3$ (Foxp3), comprise $5-10 \%$ of peripheral $\mathrm{CD}^{+} \mathrm{T}$ cells, and are known as natural $\mathrm{T}_{\text {reg }}$ cells (13). $\mathrm{CD}^{+} \mathrm{T}$ cells from G-CSF-mobilized stem cell donors are able to suppress alloproliferative responses of autologous $\mathrm{T}$ cells in a cell contact-independent manner, by acquiring a $\mathrm{T}_{\text {reg-like }}$ cytokine profile (14). G-CSF drives the in vitro differentiation of human dendritic cells that express tolerogenic markers involved in $\mathrm{T}_{\text {reg }}$ cell induction (15).

We have previously demonstrated that administration of G-CSF in mice with chronic heart lesions caused by $T$. cruzi infection improved cardiac structure and function (16). Here we investigate the immunomodulatory effects of G-CSF in a mouse model of chronic Chagas disease, by investigating the modulation of key inflammatory mediators and the participation of $\mathrm{T}_{\text {reg }}$ cells.

\section{MATERIALS AND METHODS}

\section{Animals}

Four-week-old male C57BL/6 mice were used for T. cruzi infection and as normal controls. All animals were raised and maintained at the Gonçalo Moniz Research Center, Fundação Oswaldo Cruz (FIOCRUZ) in rooms with controlled temperature $\left(22 \pm 2^{\circ} \mathrm{C}\right)$ and humidity $(55 \pm 10 \%)$ and continuous air flow. Animals were housed in a 12 h-light-dark cycle (6:00 AM-6:00 PM) and provided with rodent diet and water $a d$ libitum. Animals were handled according to the U.S. National Institutes of Health guidelines for animal experimentation. All procedures described had prior approval from the local animal ethics committee under number L-002/11 (FIOCRUZ, Bahia, Brazil).

\section{T. cruzi infection and G-CSF administration}

Trypomastigotes from the myotropic Colombian T. cruzi strain (17) were obtained from culture supernatants of infected LLC-MK2 cells. Infection of C57BL/6 mice was performed by intraperitoneal injection of $100 \mathrm{~T}$. cruzi trypomastigotes in saline. Parasitemia of infected mice was evaluated at different time points after infection by counting the number of trypomastigotes in peripheral blood aliquots. Groups of chronic chagasic mice (6 mo after infection) were treated intraperitoneally $(200 \mu \mathrm{g} / \mathrm{kg} / \mathrm{d})$ with 3 administered courses of human recombinant G-CSF (Filgrastim; Bio Sidus S.A., Buenos Aires, Argentina) for 5 consecutive d with an interval of $9 \mathrm{~d}$ between the courses (Fig. 1). Control chagasic mice received saline solution in the same regimen.

\section{Morphometric analyses}

Groups of mice were euthanized 2 mo after the therapy under anesthesia [5\% ketamine (Vetanarcol; Konig, Santana de Parnaíba, Brazil) and 2\% xylazine (Sedomin; Konig)], and hearts were removed and fixed in $10 \%$ buffered formalin. Heart sections were analyzed by light microscopy after paraffin embedding, followed by standard hematoxylin and eosin staining. Inflammatory cells infiltrating heart tissue were counted using a digital morphometric evaluation system. Images were digitized using a color digital video camera (CoolSnap, Photometrics, Montreal, QC, Canada) adapted to a BX41 microscope (Olympus, Tokyo, Japan). Morphometric analyses were performed using the software Image-Pro Plus v.7.0 (Media Cybernetics, San Diego, CA, USA). The inflammatory cells were counted in 10 fields $(\times 400$ view $) /$ heart. The percentage of fibrosis was determined using Sirius redstained heart sections and Image-Pro Plus v.7.0 to integrate the areas; 10 fields per animal were captured using $\times 200$ view. All of the analyses were performed in a blinded fashion.

\section{Confocal immunofluorescence analyses}

Frozen or formalin-fixed paraffin-embedded hearts were sectioned, and 4- $\mu$ m-thick sections were used for detection of syndecan-4, intercellular adhesion molecule-1 (ICAM-1), galectin-3, CD3, Foxp3, and interleukin (IL)-10 expression by immunofluorescence. First, paraffin-embedded sections were deparaffinized and submitted to a heat-induced antigen retrieval step by incubation in citrate buffer ( $\mathrm{pH}$ 6.0). Then, sections were incubated overnight with the following primary antibodies: anti-syndecan-4 (1:50; Santa Cruz Biotechnology,
Figure 1. Experimental design. C57BL/6 mice were infected with 100 Colombian strain T. cruzi trypomastigotes and treated during the chronic phase of infection with human recombinant $\mathrm{G}-\mathrm{CSF}$, as indicated.

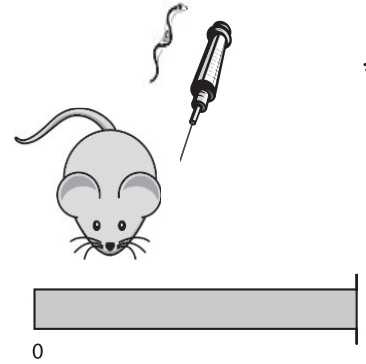

T. cruzi infection (i.p.)

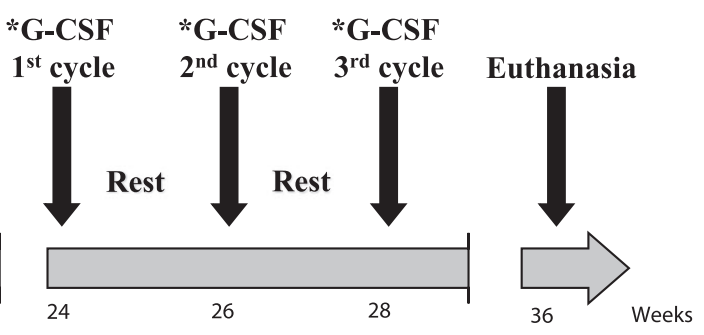

Chronic phase

*G-CSF (Filgrastim) $200 \mu \mathrm{g} / \mathrm{kg} /$ day for 5 days 
Santa Cruz, CA, USA), anti-ICAM-1 (1:50; BD Biosciences, San Jose, CA, USA), anti-CD3 (1:400; BD Biosciences), antiFoxp3 (1:400; Dako, Glostrup, Denmark), or anti-IL-10 (1: 100; BD Biosciences). On the following day, sections were incubated for $1 \mathrm{~h}$ with Alexa Fluor 633- or Alexa Fluor 488conjugated phalloidin (1:200), mixed with one of the following secondary antibodies: Alexa Fluor 594-conjugated anti-goat IgG (1:200) or Alexa Fluor 488-conjugated anti-rabbit IgG (1:200; Molecular Probes, Carlsbad, CA, USA). Nuclei were stained with 4,6-diamidino-2-phenylindole (DAPI; VectaShield Hard Set mounting medium with DAPI H-1500; Vector Laboratories, Burlingame, CA, USA). The presence of fluorescent cells was determined by observation on a FluoView 1000 confocal microscope (Olympus). Quantifications of galectin- $3^{+}$cells, syndecan $-4^{+}$blood vessels, and ICAM- $1^{+}$percentual area were performed in 10 random fields captured under $\times 400$ magnification, using Image-Pro Plus v.7.0.

\section{Real-time reverse transcription-quantitative polymerase chain reaction (RT-qPCR)}

Total RNA was isolated from heart samples with TRIzol reagent (Molecular Probes) and concentration was determined by photometric measurement. A High Capacity cDNA Reverse Transcription Kit (Applied Biosystems, Foster City, CA, USA) was used to synthesize cDNA from $1 \mu \mathrm{g}$ of RNA following the manufacturer's recommendations. RT-qPCR assays were performed to detect the expression levels of Tbet (Mm_00450960_m1), GATA3 (Mm_00484683_m1), and $G$ CSF (Mm 00438334_m1). The RT-qPCR amplification mixtures contained $20 \mathrm{ng}$ of template cDNA, TaqMan Master Mix $(10 \mu \mathrm{l})$, and probes in a final volume of $20 \mu \mathrm{l}$ (all from Applied Biosystems). All reactions were run in duplicate on an ABI 7500 sequence detection system (Applied Biosystems) under standard thermal cycling conditions. The mean $C_{t}$ (cycle threshold) values from duplicate measurements were used to calculate expression of the target gene, with normalization to an internal control $(G A P D H)$ using the $2^{-\Delta \Delta \mathrm{C} t}$ formula. Experiments with coefficients of variation $>5 \%$ were excluded. A nontemplate control and nonreverse transcription controls were also included.

\section{Flow cytometry analysis}

Quantitative analysis of $\mathrm{T}_{\text {reg }}$ cells was performed in the bone marrow and spleen of G-CSF- or saline-treated chronic chagasic mice, by flow cytometry. In brief, mice were treated with one course of G-CSF or saline and were euthanized under anesthesia the day after the final dose. Bone marrow cells were obtained from mice femurs. The bone marrow was collected by flushing the bones with Dulbecco's modified Eagle's medium (DMEM), followed by cell purification by centrifugation in Ficoll (Histopaque 1119 and 1077, 1:1; Sigma-Aldrich, St. Louis, MO, USA) gradient at $1000 \mathrm{~g}$ for 15 min. The spleens were collected, washed in DMEM, and homogenized by pressing through a $40-\mathrm{mm}$ cell strainer. Bone marrow and spleen cells were counted and resuspended in phosphate-buffered saline (PBS) buffer [1\% fetal bovine serum (FBS) in PBS]. For flow cytometry, cells were stained with labeled anti-CD4 PE-Cy5.5 and CD25 APC antibodies (BD Biosciences) for $20 \mathrm{~min}$ at room temperature. Cells were washed and analyzed using a cell analyzer (LSRFortessa; BD Biosciences) with FACSDiva software (version 6.1.3; BD Biosciences).

\section{Cytokine assessment}

Cytokine concentrations were measured in total spleen or heart protein extracts and in sera. Tissue proteins were extracted at $50 \mathrm{mg}$ of tissue $/ 500 \mathrm{ml}$ of PBS to which $0.4 \mathrm{M}$ $\mathrm{NaCl}, 0.05 \%$ Tween 20 , and protease inhibitors $(0.1 \mathrm{mM}$ phenylmethylsulfonyl fluoride, $0.1 \mathrm{mM}$ benzethonium chloride, $10 \mathrm{mM}$ EDTA, and $20 \mathrm{kIU}$ of aprotinin A/100 ml) were added. The samples were centrifuged for $10 \mathrm{~min}$ at $3000 \mathrm{~g}$, and the supernatants were immediately used in enzymelinked immunosorbent assays (ELISAs) or frozen at $-70^{\circ} \mathrm{C}$ for later quantification. Interferon- $\gamma($ IFN- $\gamma)$, tumor necrosis factor- $\alpha$ (TNF- $\alpha)$, transforming growth factor- $\beta$ (TGF- $\beta$ ), IL-4, IL-6, IL-10, or IL-17 was quantified from individual mice by ELISA using specific antibody kits (R\&D Systems, Minneapolis, MN, USA), according to the manufacturer's instructions. In brief, 96-well plates were blocked and incubated at room temperature for $1 \mathrm{~h}$. Samples were added in duplicate and incubated overnight at $4^{\circ} \mathrm{C}$. Biotinylated antibodies were added, and plates were incubated for $2 \mathrm{~h}$ at room temperature. A 0.5-h incubation with streptavidin-horseradish peroxidase conjugate was followed by detection using $3,3^{\prime}, 5,5^{\prime}$-tetramethylbenzidine peroxidase substrate and reading at $450 \mathrm{~nm}$.

\section{Quantification of parasite load}

T. cruzi DNA was quantified in heart samples by qPCR analysis. For DNA extraction, heart fragments were submitted to DNA extraction using the NucleoSpin Tissue Kit (Machenerey-Nagel, Düren, Germany), as recommended by the manufacturer. In brief, $10 \mathrm{mg}$ of each heart sample was submitted to DNA extraction, and the DNA amount and purity $(260 / 280 \mathrm{~nm})$ were analyzed by Nanodrop 2000 spectrophotometry (Thermo Fisher Scientific, Waltham, MA, USA). Kapa Probe Fast Universal 2X qPCR Master Mix was used to perform the qPCR in $20-\mu l$ reactions, including $\mathrm{ROX}$ low as the passive reference, as recommended by the manufacturer (Kapa Biosystems Inc., Woburn, MA, USA). Primers were designed based on the report by Schijman $e t$ al. (18), and the amounts used per reaction were $0.4 \mu \mathrm{M}$ concentrations of both primers (primer 1, 5'-GTTCACACACTGGACACCAA- $3^{\prime}$ and primer 2, 5' ${ }^{\prime}$-TCGAAAACGATCAGCCGAST-3') and a $0.2 \mu \mathrm{M}$ concentration of the probe (SatDNA specific probe, 5'-/56-FAM/AATTCCTCC/ZEN/ AAGCAGCGGATA/3IABkFQ/ $-3^{\prime}$ ), all included in a Mini PrimeTime qPCR assay (Integrated DNA Technologies, Inc., Coralville, IA, USA). Amounts of $1 \mu \mathrm{l}$ for each point of the standard curve, samples, and controls were applied to different wells of a PCR microplate (Axygen, Union City, CA, USA), film sealed, and submitted to amplification. Cycles were performed in an ABI 7500 system (Applied Biosystems) as follows: first, $3 \mathrm{~min}$ at $95^{\circ} \mathrm{C}$ for $\mathrm{Taq}$ activation; and second, 45 cycles at $95^{\circ} \mathrm{C}$ for $10 \mathrm{~s}$ followed by $55^{\circ} \mathrm{C}$ for $30 \mathrm{~s}$. To calculate the number of parasites per milligram of tissue, each plate contained an 8-log standard curve of DNA extracted from trypomastigotes of the Colombian T. cruzi strain (ranging from $4.7 \times 10^{-1}$ to $4.7 \times 10^{6}$ ) in duplicate. Data were analyzed using 7500 software 2.0.1 (Applied Biosystems).

\section{Assessment of trypanocidal activity}

T. cruzi epimastigotes (Colombian strain) were maintained at $26^{\circ} \mathrm{C}$ in liver infusion tryptose medium supplemented with $10 \%$ FBS, 1\% hemin (Sigma-Aldrich), 1\% R9 medium (SigmaAldrich), and $50 \mu \mathrm{g} / \mathrm{ml}$ gentamicin. Parasites were counted in a hemocytometer and then dispensed into 96-well plates at a cell density of $5 \times 10^{6}$ cells $/ \mathrm{ml}$ in the absence or presence of the human recombinant G-CSF at 3,10 , or $30 \mu \mathrm{g} / \mathrm{ml}$ in triplicate. The plate was incubated for $5 \mathrm{~d}$ at $26^{\circ} \mathrm{C}$, aliquots of each well were collected, and the number of viable parasites was counted in a Neubauer chamber. Trypomastigote forms of T. cruzi were obtained from supernatants of LLC-MK2 cells previously infected and cultured in 96-well plates at a cell 
density of $2 \times 10^{6}$ cells $/ \mathrm{ml}$ in RPMI 1640 medium (SigmaAldrich) supplemented with $10 \%$ FBS and $50 \mu \mathrm{g} / \mathrm{ml}$ gentamicin in the absence or presence of human recombinant G-CSF. After $24 \mathrm{~h}$ of incubation, the number of viable parasites, based on parasite motility, was assessed in a Neubauer chamber and compared with that of an untreated parasite culture to calculate the percentage of inhibition. Benznidazole $(30 \mu \mathrm{g} / \mathrm{ml})$ was used as a positive control. For in vitro infection, peritoneal macrophages obtained from C57BL/6 mice were seeded at a cell density of $2 \times 10^{5}$ cells $/ \mathrm{ml}$ in a 24-well plate with rounded coverslips on the bottom in RPMI 1640 medium supplemented with $10 \%$ FBS and $50 \mu \mathrm{g} / \mathrm{ml}$ gentamicin and incubated for $24 \mathrm{~h}$. Cells were then infected with trypomastigotes (1:10) for $2 \mathrm{~h}$. Free trypomastigotes were removed by successive washes using saline solution. Cultures were incubated in complete medium alone or with G-CSF $(2,6$, or $10 \mu \mathrm{g} / \mathrm{ml})$ or benznidazole $(10$ $\mu \mathrm{g} / \mathrm{ml}$ ) for $6 \mathrm{~h}$. The medium was then replaced by fresh medium, and the plate was incubated for $3 \mathrm{~d}$ at $37^{\circ} \mathrm{C}$. Cells were fixed in absolute alcohol, and the percentage of infected macrophages and the mean number of amastigotes/100 infected macrophages was determined by manual counting after hematoxylin and eosin staining using an optical microscope (Olympus).

\section{Evaluation of anti-T. cruzi antibodies}

T. cruzi-specific, total IgG, IgG1, and IgG2 antibodies were detected in the sera of naive or G-CSF- or saline-treated chronic chagasic mice by ELISA. Microtiter plates were coated overnight at $4^{\circ} \mathrm{C}$ with $T$. cruzi trypomastigote antigen $(3 \mu \mathrm{g} / \mathrm{ml})$ in $50 \mu \mathrm{l}$ of carbonate-bicarbonate buffer ( $\mathrm{pH} 9.6)$. The plates were washed 3 times with PBS containing $0.05 \%$ Tween 20 and then blocked by incubation at room temperature for $1 \mathrm{~h}$ with PBS-5\% nonfat milk. After washing, the plates were incubated with $50 \mu \mathrm{l}$ of a 1:200 (IgG) or 1:100 (IgG1 or IgG2a) dilution of each serum sample at $37^{\circ} \mathrm{C}$ for 2 $\mathrm{h}$. The plates were washed, and a 1:1000 dilution of goat anti-mouse IgG (Sigma-Aldrich) or rat anti-mouse IgG1 or IgG2a (BD Biosciences) was incubated for $1 \mathrm{~h}$ at room temperature. After washing, peroxidase-conjugated antimouse polyvalent immunoglobulins (Sigma-Aldrich) diluted 1:1000 were dispensed into each well, and the plate was incubated for $30 \mathrm{~min}$ at room temperature followed by detection using $3,3^{\prime}, 5,5^{\prime}$-tetramethylbenzidine peroxidase substrate and read at $450 \mathrm{~nm}$.

\section{Statistical analyses}

All continuous variables are presented as means \pm SEM. Morphometric and cytokine levels were analyzed using 1-way analysis of variance, followed by a Newman-Keuls multiple comparison test with Prism 3.0 (GraphPad Software, San Diego, CA, USA). All differences were considered significant at values of $P<0.05$.

\section{RESULTS}

\section{Administration of G-CSF reduces inflammation and fibrosis in hearts of chronic chagasic mice}

Multifocal inflammation, mainly composed of mononuclear cells, and fibrosis were found in the hearts of $T$. cruzi-infected mice during the chronic phase of the disease (Fig. 2A, B) . Administration of G-CSF reduced the number of inflammatory cells and the fibrotic area in chronic chagasic hearts (Fig. 2C, D). Morphometric analysis showed a statistically significant reduction of inflammation and fibrosis after G-CSF treatment, compared with the saline-treated controls (Fig. 2E, $F$ ).

\section{Reduction of syndecan-4, ICAM-1, and galectin-3 expression in the hearts of G-CSF-treated mice}

We have previously shown the overexpression of syndecan-4, ICAM-1, and galectin-3 in the hearts of chronic chagasic mice (19). To evaluate the effects of G-CSF on the expression of these inflammation markers, we performed confocal microscopy analysis in heart sections of mice from the 3 different groups. A marked decrease in syndecan- 4 production, which is highly expressed in blood vessels of chagasic hearts, was seen after G-CSF treatment (Fig. 3A, B). Morphological analyses revealed a statistically significance difference (Fig. 3C). Similarly, the expression of ICAM-1, mainly in inflammatory cells and cardiomyocytes in hearts of chronic chagasic mice, was significantly decreased after G-CSF treatment (Fig. 3D-F). Moreover, the high expression of galectin-3 in inflammatory cells was down-regulated in mouse hearts treated with G-CSF, which correlated to decreased inflammation (Fig. $3 G-I$ ).

\section{Modulation of cytokine production after G-CSF administration}

CCC has been associated with increased IFN- $\gamma$ and TNF- $\alpha$ production in mice and in humans $(19,20)$. The concentrations of these two proinflammatory cytokines were increased in heart extracts from saline-treated chagasic mice, compared with those in normal mice. The administration of G-CSF promoted a statistically significant reduction in the concentrations of both cytokines (Fig. $\mathbf{4 A}, \boldsymbol{B})$. In contrast, a significant increase in TGF- $\beta$ and IL-10 concentrations was observed in G-CSF-treated chagasic mice hearts compared with that in saline-treated controls (Fig. $4 C, D$ ). No significant differences were measured in IL-17 and IL-4 concentrations (Fig. 4E. F). Moreover, RT-qPCR analysis showed a significant decrease in Tbet gene expression after G-CSF administration (Fig. 4G), but no significant alterations in GATA3 gene expression were observed in the hearts of chronic chagasic mice (Fig. 4H).

The systemic effects of G-CSF on cytokine production were also investigated. G-CSF increased IL-10 production in the spleens of chagasic mice compared with that in uninfected and saline-treated mice (Fig. 5A). This effect was also correlated with a reversion in the overexpression of IL-17, TNF- $\alpha$, and IFN- $\gamma$ in sera or in the spleens of G-CSF-treated mice (Fig. $5 B-E$ ). In addition, G-CSF administration also induced an increase in $G-C S F$ gene expression in the spleens of chagasic mice (Fig. $5 F$ ). 

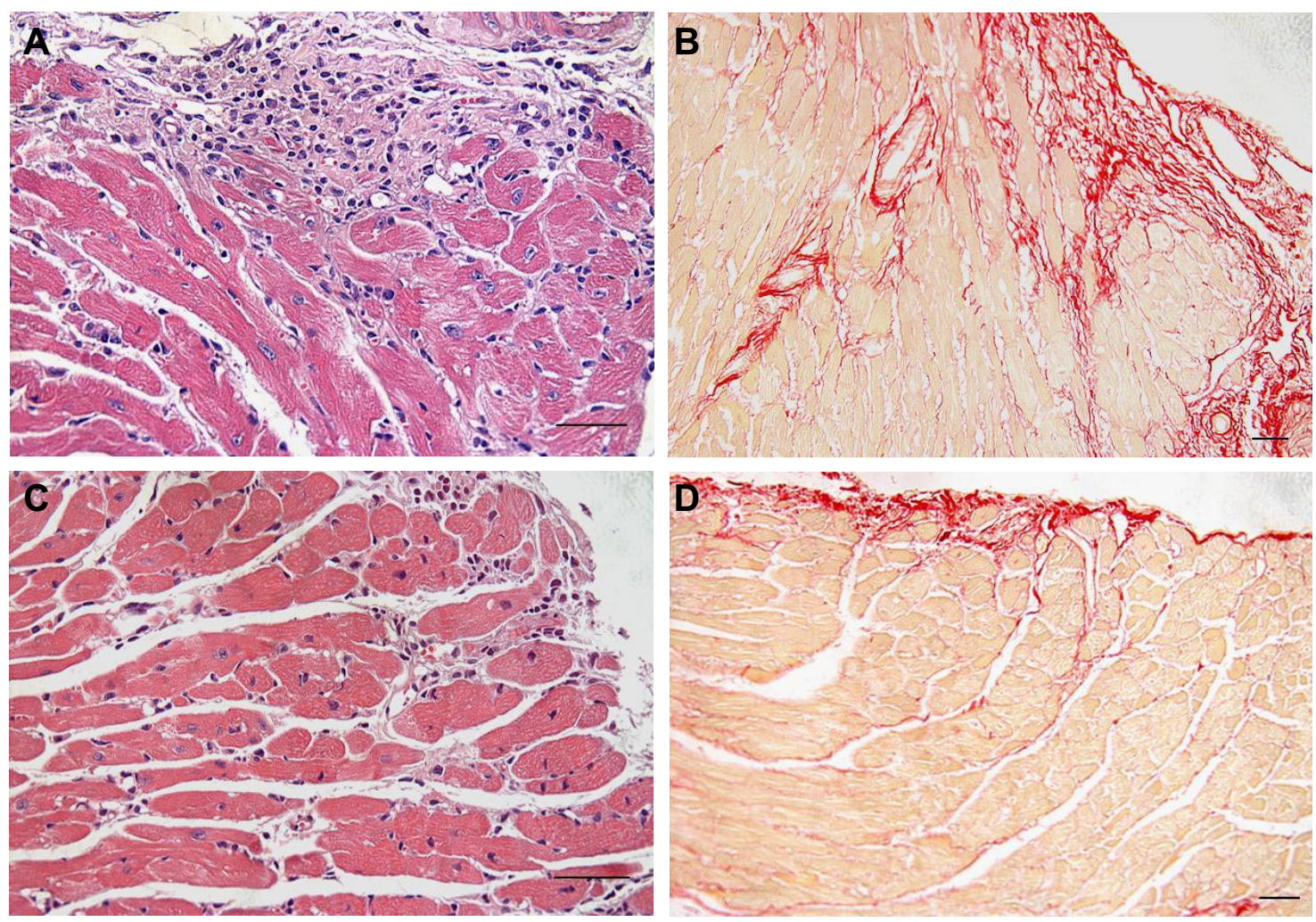

E

$\mathbf{F}$
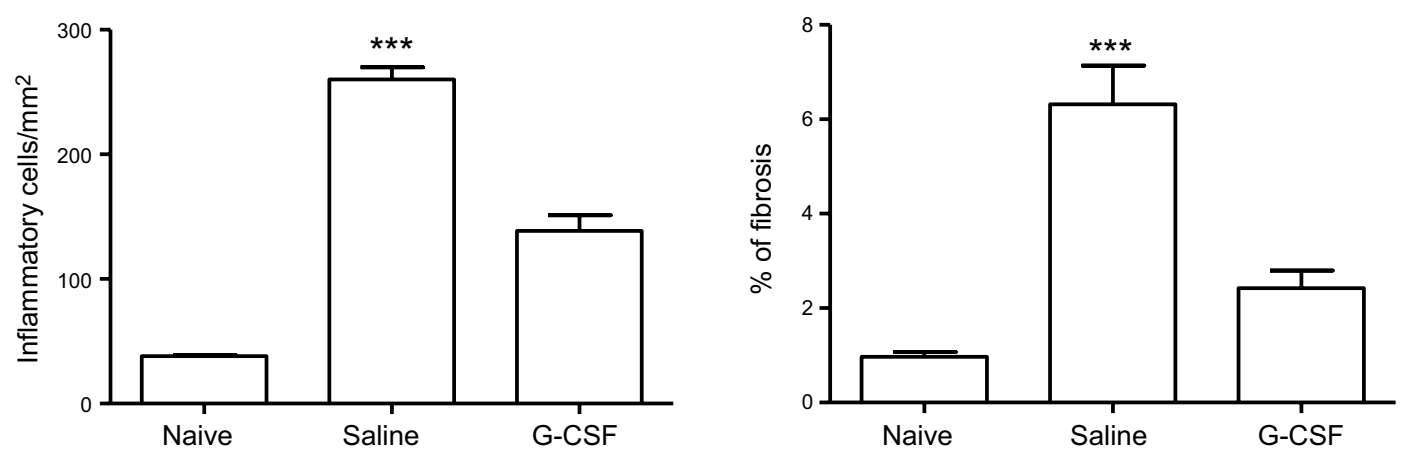

Figure 2. Reduction of inflammation and fibrosis in the hearts of chagasic mice after G-CSF administration. Groups of C57BL/6 mice in the chronic phase of infection $(6 \mathrm{mo})$ were treated with saline $(A, B)$ or G-CSF $(C, D)$. $A$, $C)$ heart sections stained with hematoxylin and eosin. $B, D$ ) Heart sections stained with Sirius red. E) Inflammatory cells were quantified in heart sections of naive mice, saline-treated chagasic mice, or G-CSF-treated chagasic mice and integrated by area. $F$ ) Fibrotic area is represented by percentage of collagen deposition in heart sections. Bars represent means \pm SEM of $9-10$ mice/group. $* * * P<0.001$.

G-CSF therapy increases the percentage of $T_{\text {reg }}$ cells in the hearts of chagasic mice

Next, we examined whether G-CSF administration altered the number of $\mathrm{T}_{\text {reg }}$ cells in chagasic mice. G-CSF caused a decrease in the percentage of $\mathrm{CD} 4{ }^{+} \mathrm{CD} 25^{+}$ cells in the bone marrow of chagasic mice (Fig. 6A-C). Foxp3 expression was analyzed in cardiac $\mathrm{CD}^{+}$cells by immunofluorescence. A higher percentage of $\mathrm{CD}^{+}$ Foxp $3^{+}$T-cell expression was found in the hearts of G-CSF-treated mice compared with those of saline-treated mice (Fig. $6 D-F$ ). A partial recovery of $\mathrm{CD} 4^{+} \mathrm{CD} 25^{+}$cells in the spleens of chagasic mice was observed after G-CSF administration (Fig. 6G), and splenic Foxp ${ }^{+}$cells coexpressed IL-10 (Fig. $6 H$ ).

\section{Effects of G-CSF administration on T. cruzi infection}

To investigate whether the suppressive response induced by G-CSF treatment affected the immune response against the parasite, we first analyzed parasitespecific antibody levels in the sera of mice from the different experimental groups. Total IgG anti-T. cruzi antibody levels were similar between G-CSF and salinetreated chagasic mice (Fig. $7 A$ ). A significant increase in IgG1 but not in IgG2 anti-T. cruzi antibodies was 

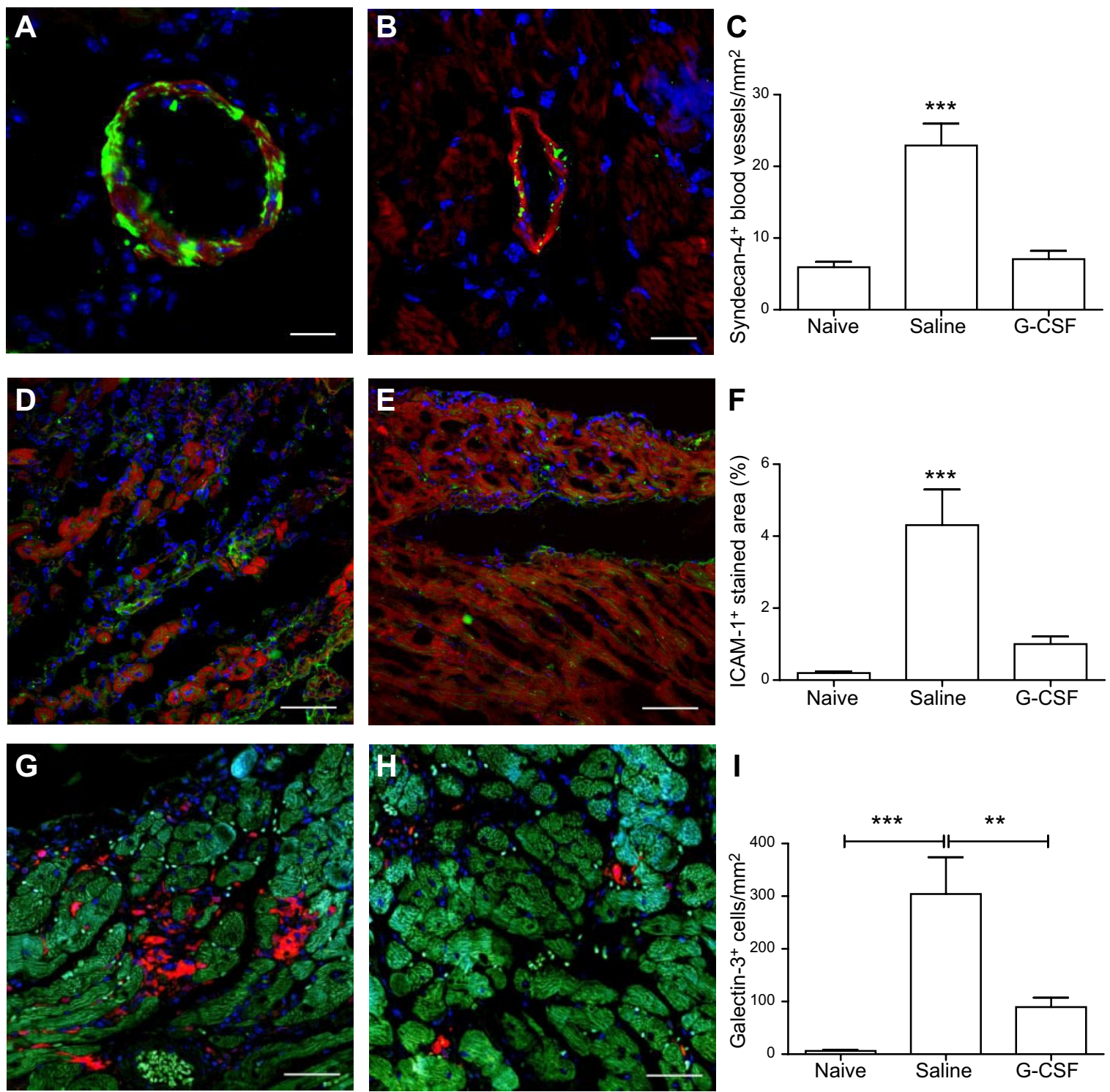

Figure 3. Reduction of syndecan-4, ICAM-1, and galectin-3 in hearts of chronic chagasic mice after G-CSF administration. Heart sections of saline-treated $(A, D, G)$ or G-CSF-treated $(B, E, H)$ mice were stained with anti-syndecan-4 (green; $A, B)$, anti-ICAM-1 (green; $D, E$ ), or anti-galectin-3 (red; $G, H$ ) antibodies. F-actin stained with phalloidin 633 (red; $A, B, D, E$ ) or 488 (green; $G$, $H)$. All sections were stained with DAPI for nuclear visualization (blue). Scale bars $=50 \mu \mathrm{m}$. $C, F, I$ ) Morphometric analyses in heart sections of naive mice or chagasic mice treated with saline or G-CSF. Bars represent means \pm SEM of 3 animals/group. $* * P<0.01 ; * * * P<0.001$

found in the group treated with G-CSF compared with the saline-treated controls (Fig. $7 B, C$ ).

To evaluate whether G-CSF administration in chronic chagasic mice affected the residual $T$. cruzi infection, we performed RT-qPCR analysis to quantify the parasite load in the hearts of the mice. As shown in Fig. $7 D$, a significant reduction in the parasite load was observed in the hearts of G-CSF-treated mice compared with that in saline-treated controls. To determine whether G-CSF acts directly on the parasite, we analyzed the effects of G-CSF on T. cruzi cultures. Addition of G-CSF at various concentrations in axenic cultures of T. cruzi epimastigotes had little effect on viability at 30 $\mu \mathrm{g} / \mathrm{ml}$ (Table 1). In contrast, a concentration-dependent trypanocidal effect was seen in cultures of isolated trypomastigotes (Table 1). In addition, when G-CSF was added to macrophage cultures infected with $T$. cruzi, a concentration-dependent decrease in the percentage of infected cells, as well as in the number of intracellular amastigotes, was observed (Fig. $7 E, F$ ).

\section{DISCUSSION}

The hallmark of CCC is the presence of a multifocal inflammatory response mainly composed of lymphocytes and macrophages, which promotes myocytolysis, fibrosis deposition, and myocardial remodeling (21). This is a progressively debilitating condition that occurs during a phase of the disease when parasitism is very scarce. Although the pathogenic mechanisms are still a matter of debate (22), the correlation of disease 
A

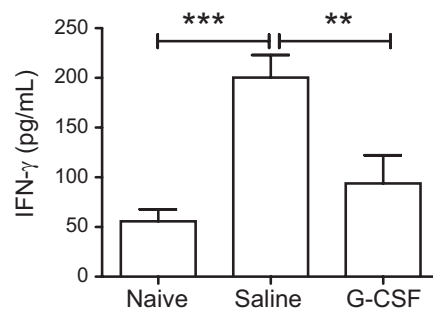

E

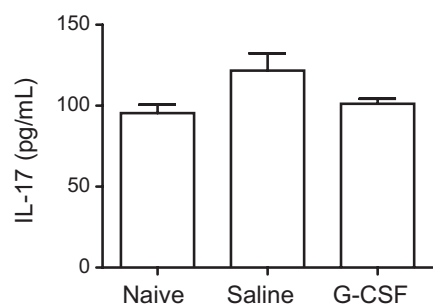

B

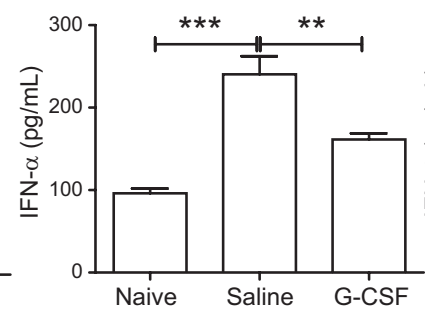

F

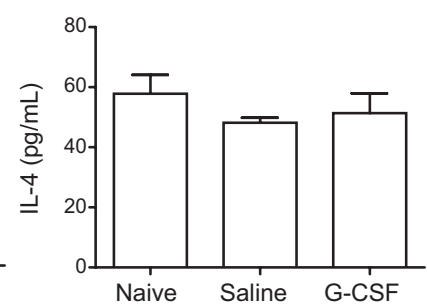

C

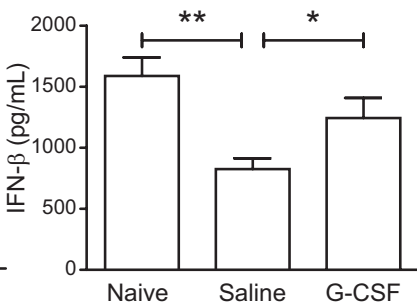

G

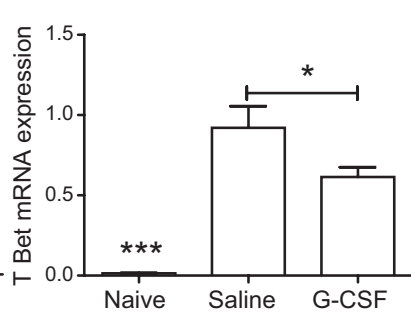

D

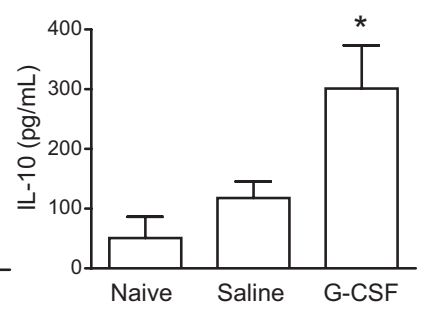

H

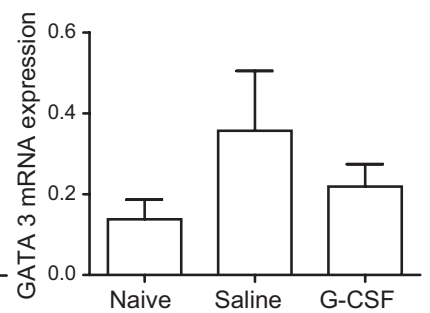

Figure 4. Modulation of cytokine production after G-CSF treatment. Concentrations of IFN- $\gamma(A)$, TNF- $\alpha(B)$, TGF- $\beta(C)$, IL-10 $(D)$, IL-17 $(E)$, and IL-4 $(F)$ were determined in heart homogenates from naive $(n=3)$ or chagasic mice treated with saline $(n=7)$ or G-CSF $(n=10)$, by ELISA. Analysis of Tbet $(G)$ and GATA3 $(H)$ was performed by real-time RT-qPCR using cDNA samples prepared from mRNA extracted from hearts of naive and chronic chagasic mice treated with saline or G-CSF $(n=9-10$ mice/group). Values represent means \pm sem. $* P<0.05 ; * * P<0.01 ; * * * P<0.001$.

severity and IFN- $\gamma$ production has been well demonstrated $(23,24)$. The fact that the parasite persists in T. cruzi-infected individuals renders any immunosuppressive condition a risk for reactivation of parasitemia $(25,26)$.

In the present study, we have demonstrated that systemic administration of G-CSF, a cytokine widely used in the clinical setting, modulates the inflammatory response, decreasing the production of key inflammatory mediators such as IFN- $\gamma$ and TNF- $\alpha$, in the main target organ, the heart. Different cytokine profiles are involved in the control of both the immune response and pathology during T. cruzi infection. The control of parasitism during the acute phase of Chagas disease is critically dependent on effective macrophage activation by cytokines, such as IFN- $\gamma$ and TNF- $\alpha$, which are
A
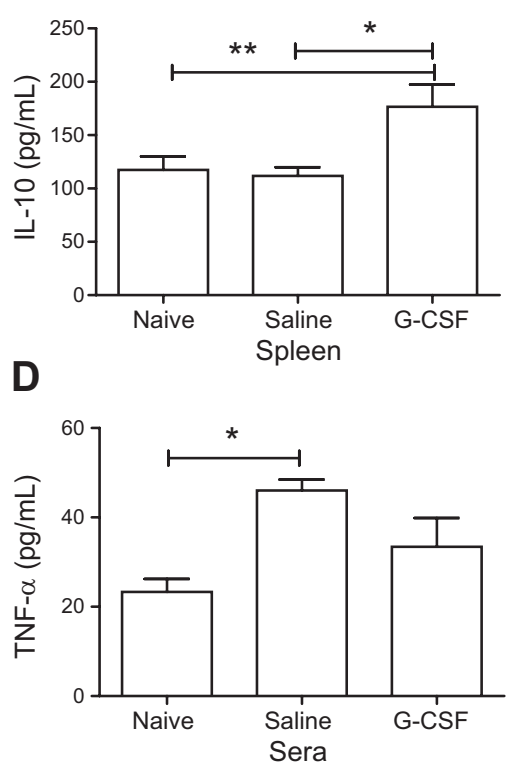

B

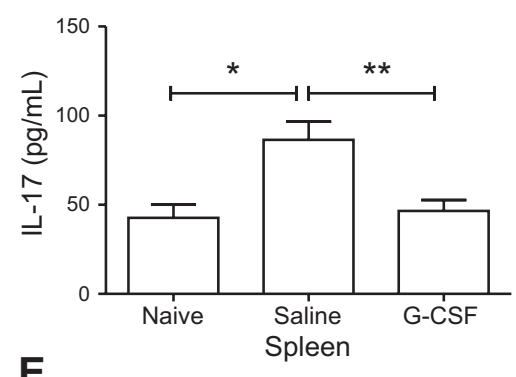

$\mathrm{E}$

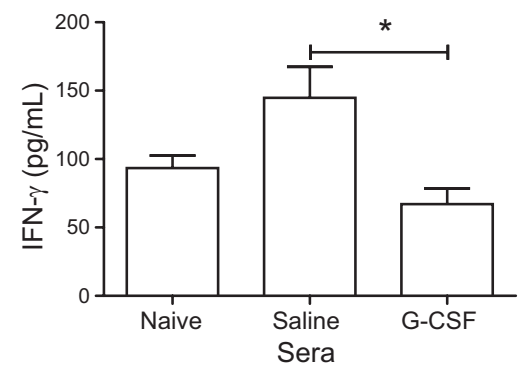

C
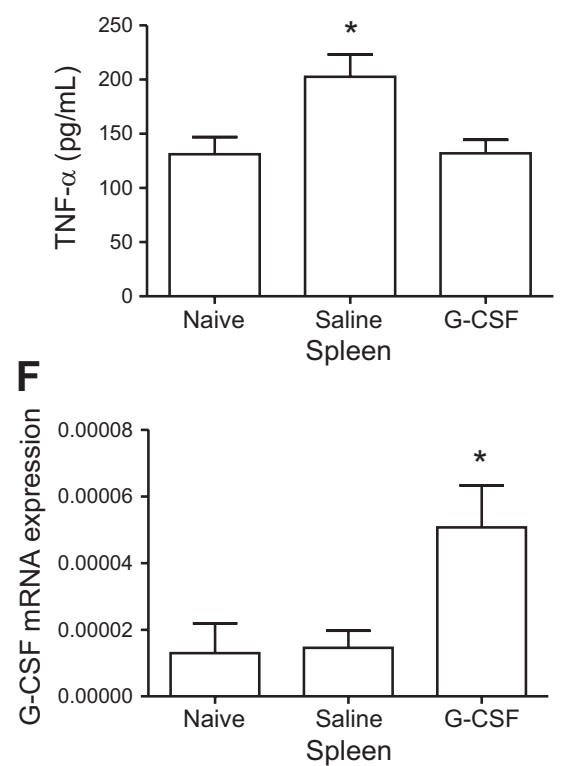

Figure 5. Modulation of systemic cytokine production in chronic chagasic mice treated with G-CSF. A-E) Concentrations of IL-10 $(A)$, IL-17 $(B)$, and TNF- $\alpha(C)$ were determined by ELISA in spleen homogenates and TNF- $\alpha(D)$ and IFN- $\gamma(E)$ in the sera from naive $(n=3)$ and chagasic mice treated with saline $(n=7)$ or G-CSF $(n=10)$. $F)$ G-CSF mRNA expression was determined by real-time RT-qPCR using cDNA samples prepared from mRNA extracted from spleens of naive and chronic chagasic mice treated with saline or G-CSF. Values represent means \pm SEM. $* P<0.05 ; * * P<0.01$. 
A
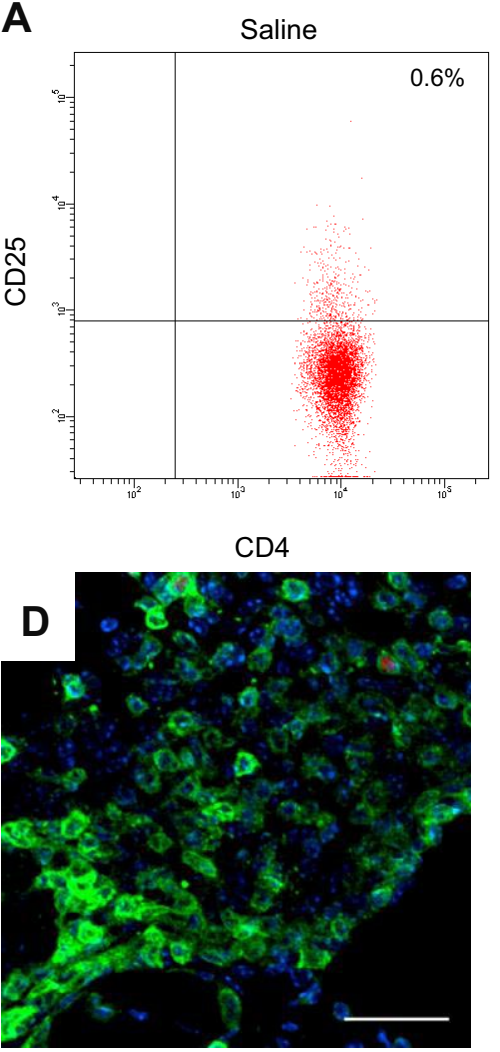

G

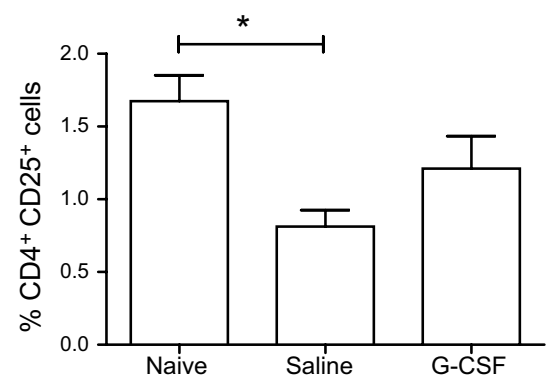

B
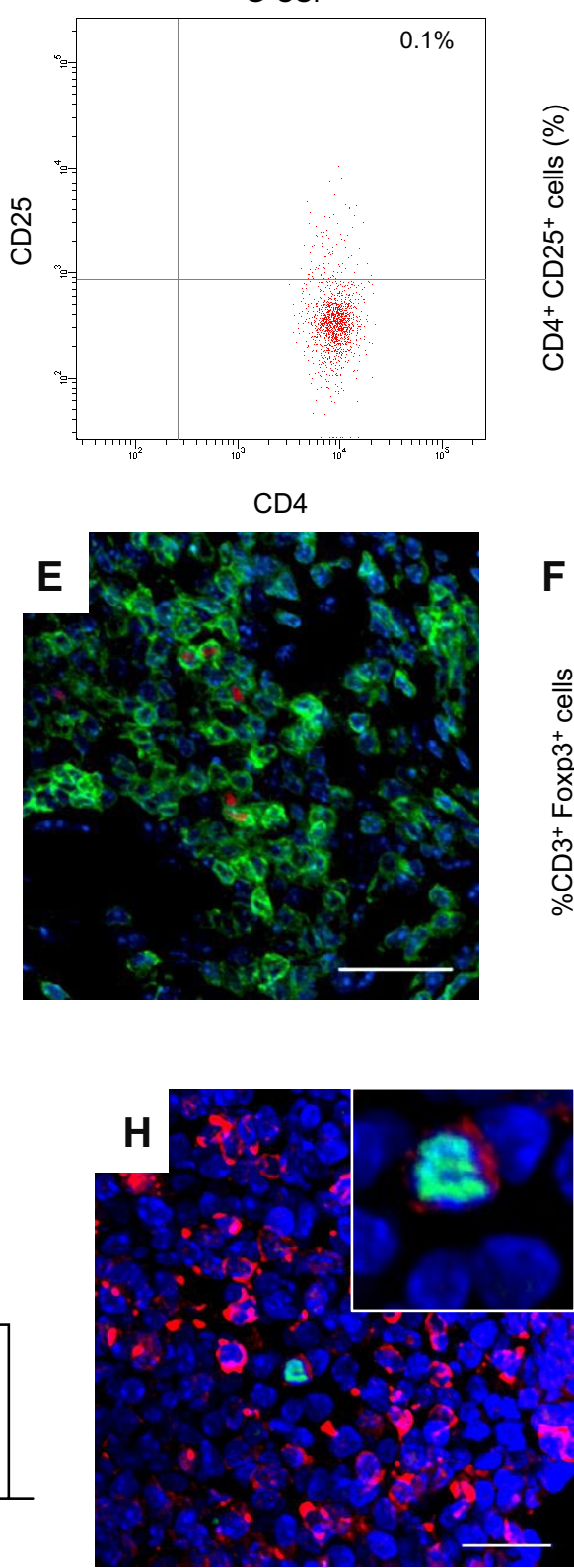

$\mathbf{F}$
C
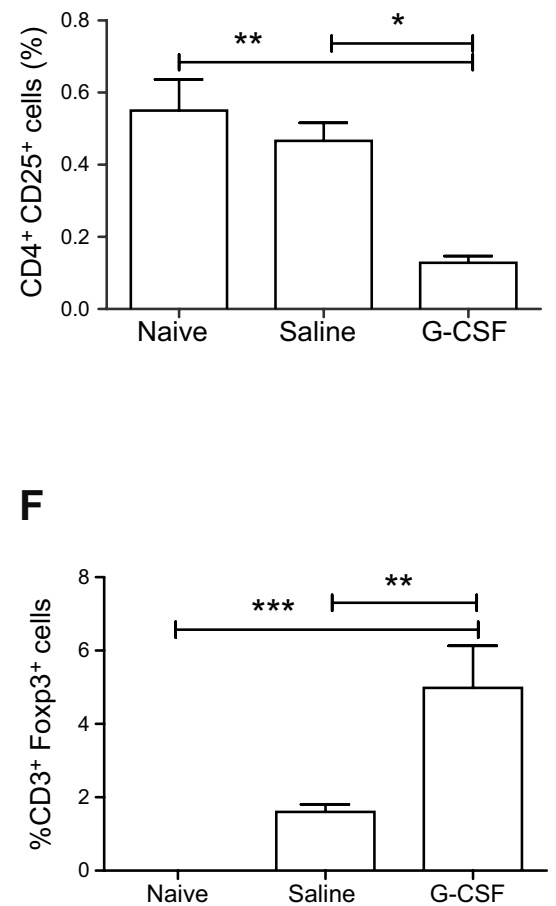

Figure 6. Mobilization of $\mathrm{T}_{\text {reg }}$ cells after G-CSF administration. $A, B)$ Flow cytometry analysis of bone marrow cells obtained from chagasic mice treated with saline $(A)$ or one course of G-CSF $(B)$. C) Quantification of $\mathrm{CD} 4^{+} \mathrm{CD} 25^{+}$ cells was evaluated in the bone marrow of naive and chagasic mice treated with saline or GCSF. D, E) Foxp3 expression (red) in $\mathrm{CD}^{+}$cells (green) was evaluated in heart sections of mice treated with saline $(D)$ or G-CSF $(E)$ by immunofluorescence ( $n=4$ /group). Nuclei (blue) were stained with DAPI. $F$ ) Quantification of $\mathrm{CD}^{+} \mathrm{Foxp}^{+}$cells in hearts of naive and chagasic mice treated with saline or G-CSF. G) Quantification of
$\mathrm{CD} 4{ }^{+} \mathrm{CD} 25^{+}$cells was evaluated in the spleens of naive and chagasic mice treated with saline or G-CSF. Bars represent means \pm SEM. $H$ ) Spleen section of a G-CSF-treated mouse, stained with anti-Foxp3 (green) and anti-IL-10 (red) antibodies. Nuclei (blue) were stained with DAPI. $* P<0.05$; $* * P<0.01 ; * * * P<0.001$. crucial for limiting parasite replication $(20,27)$. On the other hand, an intense Th1 response will enhance heart inflammation (23), and elevated TNF- $\alpha$ may affect cardiomyocyte contraction (28). Exacerbated production of IFN- $\gamma$ against $T$. cruzi antigens favors the development of a strong Th1 response in symptomatic cardiac patients, which leads to the progression of heart disease $(20,29)$. Despite the observed suppression of IFN- $\gamma$ and TNF- $\alpha$ after G-CSF administration in chagasic mice, this therapy did not increase the parasite load, suggesting that the immune response against the parasite is still effective.

Previous reports have shown immune deviation induced after G-CSF treatment (30). In our model of
Chagas disease, we did not observe an increase in IL-4, a marker of the Th2-type response. In addition, we found a significant decrease in Tbet mRNA, a transcriptional factor essential for Th1-polarized immune responses, but we did not observe a significant difference in gene expression levels for GATA3, essential for Th2 responses, in the hearts of G-CSF-treated mice. Therefore, our results do not indicate a shift toward a Th2 profile after G-CSF administration in chagasic mice, but rather a suppression of the Th1-type immune response found in chronic chagasic mice.

In addition to cytokines, the expression of adhesion molecules important to cell migration, such as syndecan-4 and ICAM-1, already shown to be elevated in the 
A
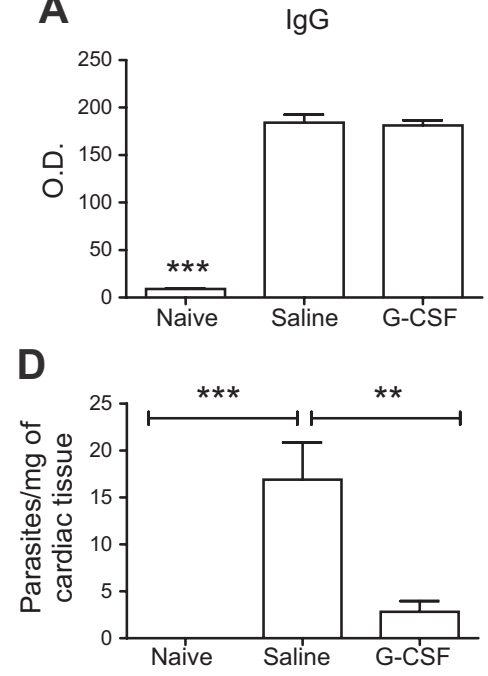

B

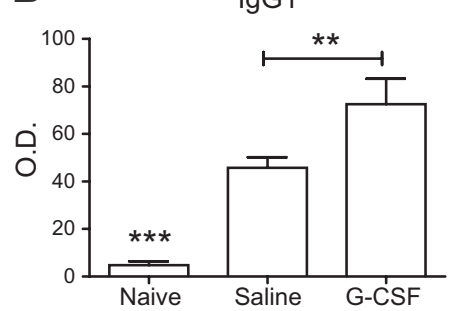

E

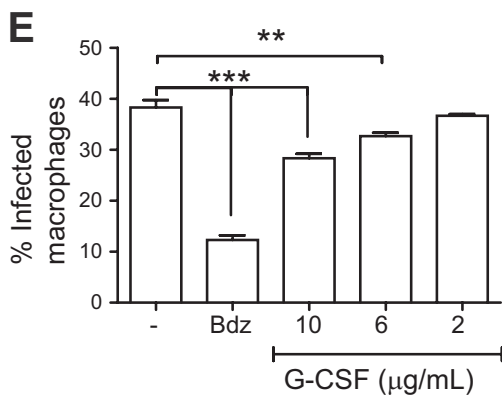

C

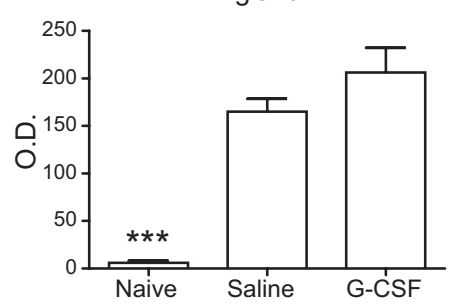

$\mathbf{F}$

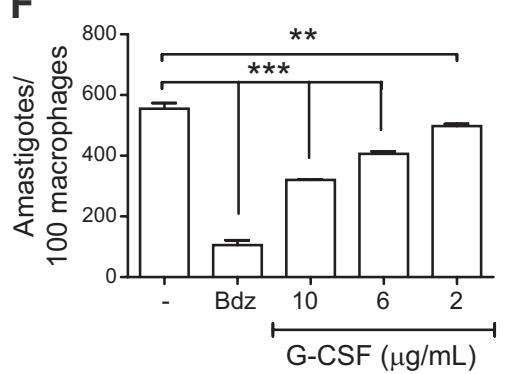

Figure 7. Effects of G-CSF on anti-T. cruzi antibody production and on the parasite. $A-C$ ) Serum samples from normal and T. cruzi-infected mice treated with saline or G-CSF (3 courses) were obtained 2 mo after treatment. Anti- $T$. cruzi levels of total IgG $(A)$, IgG1 $(B)$, and IgG2 $(C)$ antibodies were determined by ELISA. Bars represent means \pm sEM of $5-10$ mice/group. $D)$ Heart fragments obtained from normal and T. cruzi-infected mice treated with saline or G-CSF (3 courses) were used for DNA extraction and RT-qPCR analysis for quantification of parasite load. $E, F$ ) Mouse peritoneal macrophages were infected with $T$. cruzi and treated with G-CSF $(3$ and $10 \mu \mathrm{g} / \mathrm{ml})$ or benznidazole $(10 \mu \mathrm{g} / \mathrm{ml})$, a standard drug. Numbers of infected cells $(E)$ and amastigotes $(F)$ were determined by counting hematoxylin and eosin-stained cultures. Values represent means \pm SEM of triplicate determinations obtained in 1 of 2 experiments performed. $* * P<0.01 ; * * * P<0.001$.

hearts of chronic chagasic mice $(19,29)$, was reduced after G-CSF therapy. TNF- $\alpha$ induces ICAM-1 expression, thus increasing endothelial adhesiveness for leukocytes (31). Syndecan-4 is a transmembrane heparan sulfate proteoglycan that acts cooperatively with integrins in generating signals necessary for the assembly of actin stress fibers and focal adhesions (32-34). Because $\mathrm{TNF}-\alpha$ up-regulates syndecan-4 expression (35), the decreased expression in endothelial cells in the hearts of chagasic mice may be a consequence of the TNF- $\alpha$ down-regulation observed after G-CSF administration. Taken together, the decreases in syndecan-4 and ICAM-1 may contribute to a reduction in cell migration into the myocardium and, consequently, reduced inflammation.

Another important action of G-CSF in the Chagas disease model, as well as in other models of ischemic heart disease, is reduced fibrosis $(17,36)$. This may be due to the modulation in the heart of fibrogenic

TABLE 1. Effects of G-CSF in axenic cultures of T. cruzi (Colombian strain)

\begin{tabular}{lrcc}
\hline \hline & & \multicolumn{2}{c}{ \% Inhibition } \\
\cline { 3 - 4 } Drug & $(\mu \mathrm{g} / \mathrm{ml})$ & Epimastigotes & Trypomastigotes \\
\hline G-CSF & 3 & $0.52 \pm 0.52$ & $1.90 \pm 0.90$ \\
& 10 & $2.58 \pm 0.66$ & $12.85 \pm 1.43^{*}$ \\
Benznidazole & 30 & $9.60 \pm 1.34 * *$ & $24.28 \pm 2.51^{* * *}$ \\
& 30 & $96.78 \pm 0.06 * * *$ & $100^{* * *}$ \\
\hline
\end{tabular}

Values are means \pm SEM of 3 independent experiments. $* P<$ $0.05 ; * * P<0.01 ; * * * P<0.001$. mediators, such as galectin-3, which have been shown to play important roles in fibrosis deposition and in heart failure (37). Galectin-3 expression was found in activated myocardial macrophages and is increased by IFN- $\gamma(38,39)$. In addition, the administration of recombinant galectin-3 in rats induced cardiac fibroblast proliferation, collagen production, and left ventricular dysfunction (38). Moreover, galectin-3 is known to play important roles in the regulation of inflammatory responses, including suppression of T-cell apoptosis (40). In fact, in our previous study, we observed an increase in apoptosis in the hearts of chagasic mice treated with G-CSF (16), correlating with the decrease of galectin-3 found herein.

We observed suppression of inflammatory mediators after G-CSF administration, which was accompanied by an increase in IL-10 production in the hearts and spleens of chagasic mice. This is an important regulatory cytokine already shown to be associated with an improved outcome in chronic chagasic patients (20). Studies in noninfectious disease models have shown that G-CSF administration can induce both increases in IL-10 and TGF- $\beta$ and mobilization of $\mathrm{T}_{\text {reg }}$ cells from the bone marrow $(12,41,42)$. Evidence for the suppressive effects of G-CSF-mobilized $\mathrm{T}_{\text {reg }}$ cells are shown in a model of diabetes, in which isolated G-CSF-mobilized $\mathrm{T}_{\text {reg }}$ cells protected naive recipients against diabetogenic lymphocytes (42). Natural $\mathrm{T}_{\text {reg }}$ cells have emerged as potential immune tolerance mediators after immunotherapy in allergic diseases, comprising a population of circulating $\mathrm{T}$ cells that express the IL$10^{+} \mathrm{CD} 4^{+} \mathrm{CD}_{25}{ }^{+}$phenotype involved in the ameliora- 
tion of symptoms (43-45). The coexpression of IL-10 in $\mathrm{T}_{\text {reg }}$ cells, which demonstrated increased frequency after G-CSF treatment, suggests that these cells are a source of IL-10. In fact, the production of IL-10 has been described as one of the mechanisms by which $\mathrm{T}_{\text {reg }}$ cells exert their suppressive activity (46).

G-CSF administration had a systemic effect on the immune response, as shown by the reduction in- inflammatory mediators such as TNF- $\alpha$ and IFN- $\gamma$ in the spleen and sera of chagasic mice. Although we did not observe significant alterations in IL-17 in the hearts of G-CSF-treated mice, G-CSF administration did affect splenetic IL-17 levels. In contrast to the work in naive mice performed by Hill et al. (47), we did not observe IL-17 induction after G-CSF administration in chronically infected mice. Concomitant with the reduction in inflammatory mediators, we observed increased production of IL-10 in the spleens of G-CSF-treated mice. $\mathrm{FoxP}^{+}$cells also were costained for IL-10 in the spleens of chagasic mice treated with G-CSF, suggesting a role of this cell population in the modulatory action induced by G-CSF.

$\mathrm{T}_{\text {reg }}$ cells constitute an anti-inflammatory T-cell population associated with immune regulation, which may prevent tissue damage caused by parasite-triggered immune responses (48). $\mathrm{T}_{\text {reg }}$ cells expressing $\mathrm{CD} 4{ }^{+} \mathrm{CD} 25^{+}$cells have recently been associated with the expression of the regulatory lineage factor Foxp3 and are responsible for maintaining self-tolerance $(49,50)$. The increased percentage of $T_{\text {reg }}$ cells in the spleens and lymph nodes of G-CSF-treated mice caused by mobilization of bone marrow-resident $\mathrm{T}_{\text {reg }}$ cells has been described previously (41). This mobilization of $\mathrm{T}_{\text {reg }}$ cells after G-CSF administration seems to be due to the reduced expression of SDF1, the CXCR4 ligand, in the bone marrow. Rutella et al. (51) reported that G-CSF induces an increase in $\mathrm{T}_{\text {reg }}$ cells in the peripheral blood of normal human recipients. Recent investigations evaluating the frequency of $\mathrm{T}_{\text {reg }}$ cells during early and late indeterminate forms of Chagas disease have shown a correlation between the severity of the CCC and a lower frequency or suppressive activity of $\mathrm{CD} 4{ }^{+} \mathrm{CD} 25^{+}$cells (52-54). Thus, our data corroborate these findings, because an inverse correlation between the percentage of $\mathrm{T}_{\mathrm{reg}}$ cells, inflammatory cells, and cytokines in the heart of chagasic mice was found when G-CSF- and salinetreated mice were compared.

One important issue raised was whether the suppressive effects of G-CSF could interfere with the control of T. cruzi infection. The levels of anti-T. cruzi $\operatorname{IgG}$ antibodies in the sera of chagasic mice were not reduced after G-CSF treatment. More importantly, by using a very sensitive quantification method (18), we found a decrease in parasite load in the hearts of chronic chagasic mice treated with G-CSF compared with that in saline-treated mice, suggesting that this cytokine could have a direct effect on parasite elimination. To address this question, we evaluated the effects of G-CSF in vitro, in 3 parasitic forms. Although G-CSF had little effect on the viability of epimastigote form, it did significantly affect the forms found in the mammalian hosts (trypomastigotes and amastigotes) in a concentration-dependent manner. In fact, previous reports have shown that other cytokines, such as GM-CSF and TNF- $\alpha$, can have direct effects on the parasite and interfere with $T$. cruzi infection (55). Taken together, our data indicate that parasitism reduction may be a positive effect of G-CSF therapy.

In conclusion, the present study reinforces our previous work, in which we demonstrated improvement in cardiopulmonary function after G-CSF administration, by revealing its potent anti-inflammatory properties in a model of parasite-driven heart disease. More importantly, we demonstrated the modulation of pathogenic immune responses without affecting the control of infection, a feature highly desired in the clinical setting. Finally, our results reinforce the possibility of clinical applications of G-CSF, a well-tolerated drug with few side effects, in the treatment of patients with CCC.

The authors thank Kyan Allahdadi for careful review of the article. This work was supported by grants from the Brazilian Ministry of Sciences and Technology (MCT), Conselho Nacional de Pesquisas (CNPq), Financiadora de Estudos e Projetos (FINEP), Fundação Oswaldo Cruz (FIOCRUZ), and Fundação de Amparo as Pesquisas do Estado da Bahia (FAPESB). J.F.V. and A.C.D.A. were recipients of a Coordination for the Improvement of Higher Education Personnel (CAPES) doctoral scholarship from the Universidade Estadual de Feira de Santana/Programa de Pós-graduação em Biotecnologia (UEFS/PPgBIOTEC) and Rede Nordeste de Biotecnologia (RENORBIO) graduate programs, respectively. B.S.F.S. holds a CNPq doctoral scholarship, and C.S.M. holds a FAPESB master scholarship. M.B.P.S. and R.R.-D.-S. are recipients of $\mathrm{CNPq}$ senior fellowships.

\section{REFERENCES}

1. Franco-Paredes, C., Von, A., Hidron, A., Rodríguez-Morales, A. J., Tellez, I., Barragán, M., Jones, D., Náquira, C. G., and Mendez, J. (2007) Chagas disease: an impediment in achieving the millennium development goals in Latin America. BMC Int. Health Hum. Rights 7, 1-6

2. Hotez, P. J., Bottazzi, M. E., Franco-Paredes, C., Ault, S. K., and Roses-Periago, M. (2008) The neglected tropical diseases of Latin America and the Caribbean: estimated disease burden and distribution and a roadmap for control and elimination. PLoS Negl. Trop. Dis. 2, 1-11

3. Franco-Paredes, C., Bottazzi, M. E., and Hotez, P. J. (2009) The unfinished public health agenda of Chagas disease in the era of globalization. PLoS Negl. Trop. Dis. 3, 1-4

4. World Health Organization. Chagas disease. Retrieved November 1, 2012, from http://www.who.int/mediacentre/factsheets/ fs340/en/index.html

5. Bocchi, E. A., Bellotti, G., Mocelin, A., Uip, D., Bacal, F., Higuchi, M. L., Amato-Neto, V., Fiorelli, A., Stolf, N. A., Jatene, A. D., and Pileggi, F. (1996) Heart transplantation for chronic Chagas' heart disease. Ann. Thorac. Surg. 61, 1727-1733

6. Von-Aulock, S., Boneberg, E. M., Diterich, I., and Hartung, T. (2004) Granulocyte colony-stimulating factor (filgrastim) treatment primes for increased ex vivo inducible prostanoid release. J. Pharmacol. Exp. Ther. 308, 754-759

7. Hartung, T., Docke, W. D., Gantner, F., Krieger, G., Sauer, A., Stevens, P., Volk, H. D., and Wendel, A. (1995) Effect of granulocyte colony-stimulating factor treatment on ex vivo blood cytokine response in human volunteers. Blood 85, 2482 2489 
8. Boneberg E. M., and Hartung, T. (2002) Molecular aspects of anti-inflammatory action of G-CSF. Inflamm. Res. 51, 119-128

9. Iwanaga, K., Takano, H., Ohtsuka, M., Hasegawa, H., Zou, Y., Qin, Y., Odaka, K., Hiroshima, K., Tadokoro, H., and Komuro, I. (2004) Effects of G-CSF on cardiac remodeling after acute myocardial infarction in swine. Biochem. Biophys. Res. Commun. 325, 1353-1359

10. Harada, M., Qin, Y., Takano, H., Minamino, T., Zou, Y., Toko, H., Ohtsuka, M., Matsuura, K., Sano, M., Nishi, J., Iwanaga, K., Akazawa, H., Kunieda, T., Zhu, W., Hasegawa, H., Kunisada, K., Nagai, T., Nakaya, H., Yamauchi-Takihara, K., and Komuro, I. (2005) G-CSF prevents cardiac remodeling after myocardial infarction by activating the Jak-Stat pathway in cardiomyocytes. Nat. Med. 11, 305-311

11. Higuchi, T., Yamauchi-Takihara, K., Matsumiya, G., Fukushima, N., Ichikawa, H., Kuratani, T., Maehata, Y., and Sawa, Y. (2008) Granulocyte colony-stimulating factor prevents reperfusion injury after heart preservation. Ann. Thorac. Surg. 85, 1367-1373

12. Rutella, S., Zavala, F., Danese, S., Kared, H., and Leone, G. (2005) Granulocyte colony-stimulating factor: a novel mediator of T cell tolerance. J. Immunol. 175, 7085-7091

13. Sakaguchi, S. (2005) Naturally arising Foxp3-expressing $\mathrm{CD} 25^{+} \mathrm{CD} 4^{+}$regulatory $\mathrm{T}$ cells in immunological tolerance to self and non-self. Nat. Immunol. 6, 345-352

14. Rutella, S., Pierelli, L., Bonanno, G., Sica, S., Ameglio, F., Capoluongo, E., Mariotti, A., Scambia, G., d'Onofrio, G., and Leone, G. (2002) Role for granulocyte colony-stimulating factor in the generation of human T regulatory type 1 cells. Blood 100, 2562-2571

15. Rossetti, M., Gregori, S., and Roncarolo, M. G. (2010) Granulocyte-colony stimulating factor drives the in vitro differentiation of human dendritic cells that induce anergy in naive $\mathrm{T}$ cells. Eur. J. Immunol. 40, 3097-3106

16. Macambira, S. G., Vasconcelos, J. F., Costa, C. R., Klein, W., Lima, R. S., Guimarães, P., Vidal, D. T., Mendez, L. C., RibeiroDos-Santos, R., and Soares, M. B. (2009) Granulocyte colonystimulating factor treatment in chronic Chagas disease: preservation and improvement of cardiac structure and function. FASEB J. 23, 3843-3850

17. Federici, E. E., Abelmann, W. H., and Neva, F. A. (1964) Chronic and progressive myocarditis and myositis in $\mathrm{C} 3 \mathrm{H}$ mice infected with Trypanosoma cruzi. Am. J. Trop. Med. Hyg. 13, 272-280

18. Schijman, A. G., Bisio, M., Orellana, L., Sued, M., Duffy, T., Mejia Jaramillo, A. M., Cura, C., Auter, F., Veron, V., Qvarnstrom, Y., Deborggraeve, S., Hijar, G., Zulantay, I., Lucero, R. H., Velazquez, E., Tellez, T., Sanchez Leon, Z., Galvão, L., Nolder, D., Monje Rumi, M., Levi, J. E., Ramirez, J. D., Zorrilla, P., Flores, M., Jercic, M. I., Crisante, G., Añez, N., De Castro, A. M., Gonzalez, C. I., Acosta Viana, K., Yachelini, P., Torrico, F., Robello, C., Diosque, P., Triana Chavez, O., Aznar, C., Russomando, G., Büscher, P., Assal, A., Guhl, F., Sosa Estani, S., DaSilva, A., Britto, C., Luquetti, A., and Ladzins, J. (2011) International study to evaluate PCR methods for detection of Trypanosoma cruzi DNA in blood samples from Chagas disease patients. PLoS Negl. Trop. Dis. 5, 1-13

19. Soares, M. B., de Lima, R. S., Rocha, L. L., Vasconcelos, J. F., Rogatto, S. R., dos Santos, R. R., Iacobas, S., Goldenberg, R. C., Iacobas, D. A., Tanowitz, H. B., de Carvalho, A. C., and Spray, D. C. (2010) Gene expression changes associated with myocarditis and fibrosis in hearts of mice with chronic chagasic cardiomyopathy. J. Infect. Dis. 202, 416-426

20. Gomes, J. A., Bahia-Oliveira, L. M., Rocha, M. O., Martins-Filho, O. A., Gazzinelli, G., and Correa-Oliveira, R. (2003) Evidence that development of severe cardiomyopathy in human Chagas' disease is due to a Th1-specific immune response. Infect. Immun. 71, 1185-1193

21. Köberle, F. (1968) Chagas' disease and Chagas' syndromes: the pathology of American trypanosomiasis. Adv. Parasitol. 6, 63-116

22. Soares, M.B., Silva-Mota, K.N., Lima, R.S., Bellintani, M.C., Pontes-de-Carvalho, L., and Ribeiro-dos-Santos, R. (2001) Modulation of chagasic cardiomyopathy by IL-4: dissociation between inflammatory and tissue parasitism. Am. J. Pathol. 159, 703-709

23. Soares, M. B. P., Pontes-de-Carvalho, L., and Ribeiro-dos-Santos, R. (2001) The pathogenesis of Chagas' disease: when autoim- mune and parasite-specific immune responses meet. An. Acad. Bras. Cienc. 73, 547-559

24. Bahia-Oliveira, L. M. G., Gomes, J. A. S., Rocha, M. O. S., Moreira, M. C., Lemos, E. M., Luz, Z. M., Pereira, M. E., Coffman, R. L., Dias, J. C., Cançado, J. R., Gazzinelli, G., and Corrêa-Oliveira, R. (1998) IFN- $\gamma$ in human Chagas' disease: protection or pathology? Braz. J. Med. Biol. Res. 31, 127-131

25. Galhardo, M. C. G., Martins, I. A., Hasslocher-Moreno, A., Xavier, S. S., Coelho, J. M., Junqueira, A. C., and dos Santos, R. R. (1999) Reactivation of Trypanosoma cruzi infection in a patient with acquired immunodeficiency syndrome. Rev. Soc. Bras. Med. Trop. 32, 291-294

26. Campos, S. V., Strabelli, T. M., Amato Neto, V., Silva, C. P., Bacal, F., Bocchi, E. A., and Stolf, N. A. (2008) Risk factors for Chagas' disease reactivation after heart transplantation. J. Heart Lung Transplant. 27, 597-602

27. Tadokoro, C. E., and Abrahamsohn, I. A. (2001) Bone marrowderived macrophages grown in GM-CSF or M-CSF differ in their ability to produce IL-12 and to induce IFN- $\gamma$ production after stimulation with Trypanosoma cruzi antigens. Immunol. Lett. 77, $31-38$

28. Ferrari, R. (1999) The role of TNF in cardiovascular disease. Pharmacol. Res. 40, 97-105

29. Soares, M. B., Lima, R. S., Souza, B. S. F., Vasconcelos, J. F., Rocha, L. L., Dos Santos, R. R., Iacobas, S., Goldenberg, R. C., Lisanti, M. P., Iacobas, D. A., Tanowitz, H. B., Spray, D. C., and Campos de Carvalho, A. C. (2011) Reversion of gene expression alterations in hearts of mice with chronic chagasic cardiomyopathy after transplantation of bone marrow cells. Cell Cycle 10, $1448-1455$

30. Sloand, E., Kim, S., Maciejewski, J., Van Rhee, F., Chaudhuri, A., Barrett, J., and Young, N. S. (2000) Pharmacologic doses of granulocyte colony stimulating factor affect cytokine production by lymphocytes in vitro and in vivo. Blood 95, 2269-2274

31. Ledebur, H. C., and Parks, T. P. (1995) Transcriptional regulation of the intercellular adhesion molecule-1 gene by inflammatory cytokines in human endothelial cells. Essential roles of a variant NF-кB site and p65 homodimers. J. Biol. Chem. 270, 933-943

32. Horowitz, A., Tkachenko, E., and Simons, M. (2002) Fibroblast growth factor-specific modulation of cellular response by syndecan-4. J. Cell Biol. 157, 715-725

33. Ishiguro, K., Kojima, T., and Muramatsu, T. (2003) Syndecan-4 as a molecule involved in defense mechanisms. Glycoconj. J. 19, 315-318

34. Hamon, M., Mbemba, E., Charnaux, N., Slimani, H., Brule, S., Saffar, L., Vassy, R., Prost, C., Lievre, N., Starzec, A., and Gattegno, L. (2004) A syndecan-4/CXCR4 complex expressed on human primary lymphocytes and macrophages and HeLa cell line binds the CXC chemokine stromal cell-derived factor-1 (SDF-1). Glycobiology 14, 311-313

35. Zhang, Y., Pasparakis, M., Kollias, G., and Simons, M. (1999) Myocyte-dependent regulation of endothelial cell syndecan-4 expression. Role of TNF-alpha. J. Biol. Chem. 274, 14786-14790

36. Angeli, F. S., Amabile, N., Shapiro, M., Mirsky, R., Bartlett, L., Zhang, Y., Virmani, R., Chatterjee, K., Boyle, A., Grossman, W., and Yeghiazarians, Y. (2010) Cytokine combination therapy with erythropoietin and granulocyte colony stimulating factor in a porcine model of acute myocardial infarction. Cardiovasc. Drugs Ther. 24, 409-420

37. Joo, H. G., Goedegebuure, P. S., Sadanaga, N., Nagoshi, M., and Von Bernstorff, W., and Eberlein, T. J. (2001) Expression and function of galectin-3, a $\beta$-galactoside-binding protein in activated T lymphocytes. J. Leukoc. Biol. 69, 555-564

38. Sharma, U. C., Pokharel, S., Brakel, T. J. V., van Berlo, J. H., Cleutjens, J. P., Schroen, B., André, S., Crijns, H. J., Gabius, H. J., Maessen, J., and Pinto, Y. M. (2004) Galectin-3 marks activated macrophages in failure-prone hypertrophied hearts and contributes to cardiac dysfunction. Circulation 110, 31213128

39. Reifenberg, K., Lehr, H. A., Torzewski, M., Steige, G., Wiese, E., Küpper, I., Becker, C., Ott, S., Nusser, P., Yamamura, K., Rechtsteiner, G., Warger, T., Pautz, A., Kleinert, H., Schmidt, A., Pieske, B., Wenzel, P., Münzel, T., and Löhler, J. (2007) Interferon- $\gamma$ induces chronic active myocarditis and cardiomyopathy in transgenic mice. Am. J. Pathol. 171, 463-472 
40. Rabinovich, G. A., Ramhorst, R. E., Rubinstein, N., Corigliano, A., Daroqui, M. C., Kier-Joffé, E.B., and Fainboim, L. (2002) Induction of allogenic T-cell hyporesponsiveness by galectin-1mediated apoptotic and non-apoptotic mechanisms. Cell Death Differ. 9, 661-670

41. Zou, L., Barnett, B., Safah, H., Larussa, V. F., Evdemon-Hogan, M., Mottram, P., Wei, S., David, O., Curiel, T. J., and Zou, W. (2004) Bone marrow is a reservoir for $\mathrm{CD} 4{ }^{+} \mathrm{CD} 25^{+}$regulatory $\mathrm{T}$ cells that traffic through CXCL12/CXCR4 signals. Cancer Res. 64, 8451-8455

42. Kared, H., Masson, A., Adle-Biassette, H., Bach, J. F., Chatenoud, L., and Zavala, F. (2005) Treatment with granulocyte colony-stimulating factor prevents diabetes in NOD mice by recruiting plasmacytoid dendritic cells and functional $\mathrm{CD} 4{ }^{+} \mathrm{CD} 25^{+}$regulatory T-cells. Diabetes 54, 78-84

43. Francis, J. N., Till, S. J., and Durham, S. R. (2003) Induction of IL $-10^{+} \mathrm{CD} 4^{+} \mathrm{CD} 25^{+} \mathrm{T}$ cells by grass pollen immunotherapy. $J$. Allergy Clin. Immunol. 111, 1255-1261

44. Gardner, L. M., Thien, F. C., Douglass, J. A., Rolland, J. M., and O'Hehir, R. E. (2004) Induction of T 'regulatory' cells by standardized house dust mite immunotherapy: an increase in $\mathrm{CD} 4{ }^{+} \mathrm{CD} 25^{+}$interleukin- $10^{+} \mathrm{T}$ cells expressing peripheral tissue trafficking markers. Clin. Exp. Allergy 34, 1209-1219

45. Urry, Z., Chambers, E. S., Xystrakis, E., Dimeloe, S., Richards, D. F., Gabryšová, L., Christensen, J., Gupta, A., Saglani, S., Bush, A., O'Garra, A., Brown, Z., and Hawrylowicz, C. M. (2012) The role of $1 \alpha, 25$-dihydroxyvitamin $\mathrm{D}_{3}$ and cytokines in the promotion of distinct Foxp $3^{+}$and IL- $10^{+} \mathrm{CD} 4^{+} \mathrm{T}$ cells. Eur. J. Immunol. 42, 2697-2708

46. Morris, E. S., MacDonald, K. P., Rowe, V., Johnson, D. H., Banovic, T., Clouston, A. D., and Hill, G. R. (2004) Donor treatment with pegylated G-CSF augments the generation of IL-10-producing regulatory $\mathrm{T}$ cells and promotes transplantation tolerance. Blood 103, 3573-3581

47. Hill, G. R., Olver, S. D., Kuns, R. D., Varelias, A., Raffelt, N. C., Don, A. L., Markey, K. A., Wilson, Y. A., Smyth, M. J., Iwakura, Y., Tocker, J., Clouston, A. D., and Macdonald, K. P. (2010) Stem cell mobilization with G-CSF induces type 17 differentiation and promotes scleroderma. Blood 116, 819-828

48. Belkaid, Y., Blank, R. B., and Suffia, I. (2006) Natural regulatory $\mathrm{T}$ cells and parasites: a common quest for host homeostasis. Immunol. Rev. 212, 287-300
49. Itoh, M., Takahashi, T., Sakaguchi, N., Kuniyasu, Y., Shimizu, J., Otsuka, F., and Sakaguchi, S. (1999) Thymus and autoimmunity: production of $\mathrm{CD} 25^{+} \mathrm{CD} 4^{+}$naturally anergic and suppressive $\mathrm{T}$ cells as a key function of the thymus in maintaining immunologic self-tolerance. J. Immunol. 162, 5317-5326

50. Shevach, E. M. (2009) Mechanisms of foxp $3^{+}$T regulatory cell-mediated suppression. Immunity 30, 636-645

51. Rutella, S., Bonanno, G., Pierelli, L., Mariotti, A., Capoluongo, E., Contemi, A. M., Ameglio, F., Curti, A., De Ritis, D. G., Voso, M. T., Perillo, A., Mancuso, S., Scambia, G., Lemoli, R. M., and Leone, G. (2004) Granulocyte colony-stimulating factor promotes the generation of regulatory DC through induction of IL-10 and IFN- $\alpha$. Eur. J. Immunol. 34, 1291-1302

52. Vitelli-Avelar, D. M., Sathler-Avelar, R., Dias, J. C. P., Pascoal, V. P., Teixeira-Carvalho, A., Lage, P. S., Elói-Santos, S. M., Corrêa-Oliveira, R., and Martins-Filho, O. A. (2005) Chagasic patients with indeterminate clinical form of the disease have high frequencies of circulating $\mathrm{CD}^{+} \mathrm{CD} 16^{-} \mathrm{CD} 56^{+}$natural killer $\mathrm{T}$ cells and $\mathrm{CD} 4^{+} \mathrm{CD} 25^{\mathrm{High}}$ regulatory $\mathrm{T}$ lymphocytes. Scand. J. Immunol. 62, 297-308

53. De-Araújo, F. F., Vitelli-Avelar, D. M., Teixeira-Carvalho, A., Antas, P. R., Assis Silva Gomes, J., Sathler-Avelar, R., Otávio Costa Rocha, M., Elói-Santos, S. M., Pinho, R. T., CorreaOliveira, R., and Martins-Filho, O. A. (2011) Regulatory T cells phenotype in different clinical forms of Chagas' disease. PLoS Negl. Trop. Dis. 5, 1-8

54. Guedes, P. M., Gutierrez, F. R., Silva, G. K., Dellalibera-Joviliano, R., Rodrigues, G. J., Bendhack, L. M., Rassi, A.. Jr., Rassi, A., Schmidt, A., Maciel, B. C., Marin Neto, J. A., and Silva, J. S. (2012) Deficient regulatory T cell activity and low frequency of IL-17-producing T cells correlate with the extent of cardiomyopathy in human Chagas' disease. PLoS Negl. Trop. Dis. 6, 1-11

55. Olivares-Fontt, E. O., de Baetselier, P., Heirman, C., Thielemans, K., Lucas, R., and Vray, B. (1998) Effects of granulocytemacrophage colony-stimulating factor and tumor necrosis factor alpha on Trypanosoma cruzi trypomastigotes. Infect. Immun. 66, 2722-2727

Received for publication February 20, 2013. Accepted for publication August 5, 2013. 